\title{
AGRIBISNIS PERIKANAN DI KELURAHAN AIR DINGIN KECAMATAN BUKIT RAYA KOTA PEKANBARU (STUDI KASUS PADA USAHA IKAN SALAI SEDAP)
}

\author{
Fisheries Agribusiness in Air Dingin Village, Bukit Raya District \\ of Pekanbaru City (Case Study of Ikan Salai Sedap Farm)
}

\author{
Yanti Sipahutar, Septina Elida dan Wahyu Hamidi* \\ Fakultas Pertanian Universitas Islam Riau \\ Jl. Kaharuddin Nasution No. 113 Perhentian Marpoyan-Pekanbaru \\ Fakultas Ekonomi Universitas Riau Kampus Widya Km 12,5 Pekanbaru* \\ Email : septinaelida@agr.uir.ac.id
}

\begin{abstract}
This study aims to analyze the agribusiness subsystem of the "Usaha Ikan Salai Sedap" The results of the study indicated that the applied agribusiness system has been not optimal yet. Th production finputs were sufficiently available. Business activities are carried out every day with harvesting $150 \mathrm{~kg}$ of Pangasius sp and Clarias sp. The harvesting was done selectively in accordance with the weight of the fish, i.e. 120-140 grams/tail (7-8 tails/kg) for Pangasius $s p$ and 250-300 grams/tail (3-4 tails/kg) for Claria sp. Fresh Pangasius sp and Clarias sp from farming are processed into smoked fish, and marketed through marketing institutions. Smoked fish produced from each spesies (Pangasius sp and Clarias sp) was $37.5 \mathrm{~kg}$ each). The added value obtained per $\mathrm{kg}$ of raw materials, for Pangasius sp is Rp 7,933.70, and Clarias sp was Rp. 11,760. The profit gained from Pangasius sp and Clarias sp agribusiness for the Pangasius $s p$ and Clarias $s p$ farming activities was $\mathrm{Rp} \mathrm{36,297,283.32/process,} \mathrm{and} \mathrm{Rp} \mathrm{2,233,543.96/process} \mathrm{Pangasius} s p$ and Clarias $s p$ for agroindustry activities. Profits from marketing of Pangasius sp and Clarias $s p$ was as much as $\mathrm{Rp}$ $7,419,950$. The dominant supporting subsystem in order to support the business activities of the "Usaha Ikan Salai Sedap" agribusiness was financial institutions/banks, counseling, and training.
\end{abstract}

Keywords: Agribusiness, Fisheries, Smoked Fish, Pangasius sp, Clarias sp

\begin{abstract}
ABSTRAK
Penelitian ini bertujuan untuk menganalisis subsistem agribisnis pada "Usaha Ikan Salai Sedap" Hasil penelitian menunjukkan bahwa sistem agribisnis yang diterapkan belum maksimal. Sarana produksi cukup tersedia. Kegiatan usaha dilakukan setiap hari, dengan jumlah ikan patin dan lele yang dipanenkan masing-masing $150 \mathrm{~kg}$. Pemanenan dilakukan secara selektif sesuai dengan bobot ikan yaitu berat ikan lele 120-140 gram/ekor (7-8 ekor/kg) dan ikan patin 250-300 gram/ekor (3-4 ekor $/ \mathrm{kg}$ ). Ikan patin dan lele segar hasil usahatani diolah menjadi ikan salai, dan dipasarkan melalui lembaga pemasaran. Ikan salai patin dan lele yang dihasilkan masing-masing 37,5 kg). Nilai tambah yang diperoleh per kg bahan baku, untuk ikan salai patin $\mathrm{Rp} 7.933,70$,- dan ikan salai lele Rp 11.760. Keuntungan yang diperoleh dari usaha agribisnis ikan patin dan lele, pada kegiatan usahatani ikan patin dan lele yaitu sebesar Rp 36.297.283,32/proses produksi, kegiatan agroindustri ikan salai patin dan lele yaitu sebesar Rp 2.233.543,96/porses produksi, dan keuntungan dari pemasaran ikan salai lele dan patin sebesar $\mathrm{Rp} 7.419 .950,-$. Subsistem penunjang yang dominan, terkait dalam mendukung kegiatan usaha agribisnisnis "Usaha Ikan Salai Sedap" yaitu lembaga keuangan/Bank, penyuluhan \& pelatihan.
\end{abstract}

Kata kunci: Agribisnis, Perikanan, Ikan Salai, Ikan Patin, Ikan Lele 


\section{PENDAHULUAN}

Usaha budidaya perikanan terutama budidaya perbesaran ikan saat ini diminati masyarakat di Kota Pekanbaru. Usaha ini tersebar hampir disemua kecamatan, rumah tangga yang melakukan kegiatan ini sebanyak 2.657 rumah tangga, dengan luas lahan pada umumnya 0,5 hektar. Data statistik budidaya perikanan kota Pekanbaru tahun 2018, menunjukkan jenis ikan yang umum dibudidayakan adalah ikan nila, gurame, patin dan lele, namun masyarakat lebih memilih jenis ikan patin dan lele karena masa pemeliharaannya lebih cepat disbanding jenis lainnya, memiliki resiko yang lebih ringan. Selain itu, usaha budidaya ikan patin dan lele juga tidak memerlukan teknologi tinggi, sehingga semua orang dapat membudidayakannya. Produksi ikan hasil budidaya yang tertinggi pada tahun 2018 adalah ikan lele yaitu $5.816,23$ ton disusul ikan patin dengan produksi 2.026,04 ton.

Kecamatan Bukit Raya merupakan salah satu sentra produksi perikanan budidaya kolam di Kota Pekanbaru. Ikan patin dan ikan lele merupakan jenis ikan air tawar yang banyak dibudidayakan. Ikan ini sangat lahap menelan pakan buatan berupa pellet atau pakan jenis lainnya (Djarijah AS, 2001). Ikan ini biasanya dijual secara lokal dalam bentuk segar atau diproses bentuk fillet beku untuk konsumsi domestik dan internasional, karena rasanya yang enak dengan kualitas yang diinginkan seperti dagingnya putih, lembut, kadar lemak rendah dan kandungan protein yang mudah dicerna (Bakar, at.all. 2018). Ikan patin juga dapat diolah menjadi abon (Hamidi, 2016).

Kebutuhan ikan berdasarkan preferensi konsumen Kota Pekanbaru pada periode 20151017, menunjukan bahwa ikan patin dan lele setiap tahunnya dibutuhkan dalam jumlah yang cukup tinggi dibandingkan jenis ikan lainnya, yaitu 5.576 ton pada tahun 2015, 6.111,11 ton pada tahun 2016 dan pada tahun 2017 sebanyak 9.870 ton. Perspektif masyarakat yang tinggi terhadap ikan patin dan lele menyebabkan permintaan terhadap ikan patin dan lele juga meningkat, sehingga cukup menjanjikan bagi pengusaha ikan patin dan lele. Pemenuhan kebutuhan ikan perlu memperhatikan ketersediaan ikan yang akan dikonsumsi. Pemberian pakan dengan kualitas dan kuantitas yang baik akan mengoptimalkan usaha budiaya ikan sehingga ketika produksi terus menerus ada maka kebutuhan ikan untuk rumah tangga akan terjamin (Kurniasih, dkk 2014 dalam Bokings 2017).

Bisnis pada sektor perikanan merupakan salah satu bisnis yang sangat menjanjikan. Selain karena kebutuhan pasokan pangan yang sangat tinggi, bisnis pada sektor perikanan juga berkembang baik sejalan dengan perubahan pola pikir masyarakat untuk lebih sehat (Puspita dan Wiyono, 2014).

"Usaha Ikan Salai Sedap" merupakan salah satu usaha perikanan yang terdapat di Kelurahan Air Dingin Kecamatan Bukit Raya. Kegiatan usaha perikanan yang dilakukan adalah pembesaran dan pengolahan hasil. Jenis ikan yang dipilih untuk di usahakan adalah ikan patin dan ikan lele, karena kemudahan dalam mengelola, resiko yang lebih ringan dibandingkan jenis ikan lainnya, nilai ekonomi cukup tinggi, cocok untuk diolah menjadi ikan salai dan preferensi konsumen terutama masyarakat pekanbaru terhadap produk olahan (ikan salai patin dan lele) tinggi.

Pengusaha ikan salai sedap sudah menjalankan usaha selama 9 tahun, dan jika di amati usaha ini telah menerapkan pembangunan perikanan dengan pendekatan agribisnis. Menurut Firdaus (2012), agribisnis menurut pandangan secara luas, mencakup semua kegiatan mulai dari pengadaan sarana produksi pertanian (farm supplies) sampai dengan tata niaga produk pertanian yang dihasilkan usahatani atau hasil olahannya. Semua aktivitas mulai dari pengadaan, prosesing, penyaluran sampai pada pemasaran produk yang dihasilkan oleh suatu usahatani atau agroindustri yang saling terkait satu sama lain diartikan sebagai agribisnis (Maulidah, 2012). Dengan demikian sistem agribisnis merupakan rangkaian kegiatan yang berkesinambungan mulai dari hulu sampai hilir (Saragih, 2004). Pada "Usaha Ikan Salai Sedap" pengusaha melaksanakan aktifitas pembesaran ikan dan mengolah produknya (ikan patin dan lele) menjadi ikan salai. Ikan patin dan lele pemanenannya secara selektif, ikan yang sudah memenuhi bobot yang sudah ditetapkan yaitu untuk ikan patin dengan berat 250-300 gram/ekor (berkisar 3-4 ekor/kg) dan ikan lele 120-140 gram/ekor (berkisar 7-8 ekor $/ \mathrm{kg}$ ) langsung dipanenkan dan jika tidak memenuhi bobot yg ditentukan maka akan dilepas kembali 
ke kolam. Ikan segar hasil tangkapan langsung diolah menjadi ikan salai dan kemudian dipasarkan. Secara keseluruhan kegiatan yang dilakukan cukup memberikan keberlanjutan usahanya, dan telah menerapkan sistem agribisnis, namun belum maksimal, oleh sebab itu perlu dilakukan penelitian bagaimana sistem agribisnis yang diterapkan yang mencakup subsistem-subsistemnya.

\section{METODE PENELITIAN}

Penelitian dilakukan dengan menggunakan metode survey, yang dilakukan pada "Usaha Ikan Salai Sedap" di Kelurahan Air Dingin Kecamatan Bukit Raya Kota Pekanbaru. Responden adalah pemilik Usaha Ikan Sedap dan tenaga kerjanya, serta pengelola 5 pusat oleh-oleh di Pekanbaru. Data yang dikumpulkan dalam penelitian ini adalah data primer dan data sekunder. Data primer merupakan data yang dikumpulkan dari pihak pertama, yang biasanya dapat dilakukan melalui wawancara Arikunto (2010), sedangkan, data sekunder menurut Silalahi (2012), merupakan data yang dikumpulkan dari sumber-sumber lain yang sudah tersedia sebelum penelitian dilakukan.

Data dalam penelitian ini di analisis secara deskriptif kualitatif dan kuantitatif, serta menggunakan rumus-rumus. Kegiatan pada "Usaha Ikan Selai Sedap" meliputi budidaya ikan patin dan lele, serta pengolahan ikan patin dan lele menjadi ikan salai.

\section{Biaya Produksi}

Menurut Firdaus (2008), biaya total merupakan keseluruhan jumlah biaya produksi yang dikeluarkan. Untuk menghitung biaya total dengan rumus berikut:

$\mathrm{TC}=\mathrm{TFC}+\mathrm{TVC}$

a) Usahatani

$\mathrm{TC}=\left\{\left(\mathrm{X}_{1} \mathrm{PX}_{1}\right)+\left(\mathrm{X}_{2} \mathrm{PX}_{2}\right)\left(\mathrm{X}_{3} \mathrm{PX}_{3}\right)+\left(\mathrm{X}_{4} \mathrm{PX}_{4}\right)+\right.$ $\left.\left(\mathrm{X}_{5} \mathrm{PX}_{5}\right)_{+}\left(\mathrm{X}_{6} \mathrm{PX}_{6}\right)\right\}+\mathrm{D}$

Keterangan :

$\mathrm{TC}=$ Total Biaya $(\mathrm{Rp} /$ Proses produksi $)$

$\mathrm{TVC}=$ Total biaya variabel $(\mathrm{Rp} /$ Proses produksi)

$\mathrm{X}_{1} \quad=$ Jumlah penggunaan bibit ikan patin (ekor/proses produksi)

$\mathrm{PX}_{1}=$ Harga bibit ikan patin (Rp/ekor)

$\mathrm{X}_{2} \quad=$ Jumlah penggunaan bibit ikan lele (ekor/proses produksi)

$\mathrm{PX}_{2}=$ Harga bibit ikan lele (Rp/ekor)
Penelitian ini bertujuan untuk menganalisis subsistem pada agribisnis "Usaha Ikan Salai Sedap" meliputi subsistem penyediaan sarana produksi usahatani, subsistem usahatani, subsistem agroindustri, subsistem pemasaran, dan subsistem layanan penunjang agribisnis.

$$
\begin{aligned}
& \mathrm{X}_{3}=\text { Jumlah penggunaan Tenaga Kerja } \\
& \text { (HOK/proses produksi) } \\
& \mathrm{PX}_{3}=\text { Upah tenaga kerja }(\mathrm{Rp} / \text { proses } \\
& \text { produksi) } \\
& \mathrm{X}_{4}=\text { Jumlah penggunaan pakan patin } \\
& \text { (Kg/proses produksi) } \\
& \mathrm{PX}_{4} \quad=\text { Harga pakan patin }(\mathrm{Rp} / \mathrm{Kg}) \\
& \mathrm{X}_{5} \quad=\text { Jumlah penggunaan pakan lele } \\
& (\mathrm{Kg} / \text { proses produksi) } \\
& \mathrm{PX}_{5} \quad=\text { Harga pakan lele }(\mathrm{Rp} / \mathrm{Kg})
\end{aligned}
$$

b) Agroindustri

$\mathrm{TC}=\left\{\left(\mathrm{X}_{1} \mathrm{PX}_{1}\right)+\left(\mathrm{X}_{2} \mathrm{PX}_{2}\right)+\left(\mathrm{X}_{3} \mathrm{PX}_{3}\right)+\right.$ $\left.\left(\mathrm{X}_{4} \mathrm{PX}_{4}\right)\right\}+\mathrm{D}$

Keterangan:

$\mathrm{X}_{1}=$ Jumlah penggunaan bahan baku ikan patin (Kg/proses produksi)

$\mathrm{PX}_{1} \quad=$ Harga bahan baku ikan patin $(\mathrm{Rp} / \mathrm{Kg})$

$\mathrm{X}_{2} \quad=$ Jumlah penggunaan bahan baku ikan lele ( $\mathrm{Kg} /$ proses produksi)

$\mathrm{PX}_{2} \quad=$ Harga bahan baku ikan lele $(\mathrm{Rp} / \mathrm{Kg})$

$\mathrm{X}_{3}=$ Jumlah penggunaan tenaga kerja (HOK/proses produksi)

$\mathrm{PX}_{3}=$ Upah tenaga kerja $(\mathrm{Rp} /$ proses produksi)

$\mathrm{X}_{4}=$ Jumlah penggunaan bahan pendukung (Unit/proses produksi)

$\mathrm{PX}_{4} \quad=$ Harga bahan pendukung $(\mathrm{Rp} /$ proses produksi) $\mathrm{TFC}=\underset{\text { produksi })}{\text { Total biaya tetap) }}(\mathrm{Rp} /$ proses

\section{Pendapatan}

Pendapatan yang diperoleh pengusaha pada "Usaha ikan Salai Sedap" dapat dihitung menggunakan rumus menurut Soekartawi (2006). Pendapatan kotor ditentukan dengan rumus:

$\mathrm{TR}=\left(\mathrm{Y}_{1} \cdot \mathrm{Py}_{1}\right)+\left(\mathrm{Y}_{2} \cdot \mathrm{Py}_{2}\right)$

Keterangan:

$\mathrm{TR}=$ Pendapatan kotor $(\mathrm{Rp} /$ Proses produksi $)$

$\mathrm{Y}_{1}=$ Produksi ikan salai patin $(\mathrm{Kg} /$ Proses produksi) 
$\mathrm{Y}_{2}=$ Produksi ikan salai lele $(\mathrm{Kg} /$ Proses produksi)

$\mathrm{Py}_{1}=$ Harga ikan salai patin $(\mathrm{Rp} / \mathrm{Kg})$

$\mathrm{Py}_{2}=$ Harga ikan salai lele $(\mathrm{Rp} / \mathrm{Kg})$

Pendapatan bersih ditentukan dengan rumus:

$\pi=\mathrm{TR}-\mathrm{TC}$

Keterangan:

$\pi \quad=$ Pendapatan bersih (Rp/proses produksi)

$\mathrm{TR}=$ Total penerimaan $(\mathrm{Rp} /$ proses produksi $)$

$\mathrm{TC}=$ Total Biaya $(\mathrm{Rp} /$ proses produksi $)$

\section{Efisiensi}

Efisiensi usaha dianalisis dengan menggunakan rumus Return Cost Ratio (RCR) (Soekartawi, 2006) sebagai berikut:

$\mathrm{RCR}=\frac{\mathrm{TR}}{\mathrm{TC}}$.

Tabel 1. Perhitungan Nilai Tambah Metode Hayami

\begin{tabular}{|c|c|c|}
\hline No & Variabel & Nilai \\
\hline \multicolumn{3}{|c|}{ Output, Input, dan Harga } \\
\hline 1 & Output (Kg) & (1) \\
\hline 2 & Bahan Baku (Kg) & (2) \\
\hline 3 & Tenaga Kerja Langsung (HOK) & (3) \\
\hline 4 & Faktor Konversi & $(4)=(1) /(2)$ \\
\hline 5 & Koefisien Tenaga Kerja (HOK/Kg) & $(5)=(3) /(2)$ \\
\hline 6 & Harga Output (Rp/Kg) & (6) \\
\hline 7 & Upah Tenaga Kerja (Rp/HOK) & (7) \\
\hline \multicolumn{3}{|c|}{ Penerimaan dan Keuntungan } \\
\hline 8 & Harga Bahan Baku (Rp/Kg) & (8) \\
\hline 9 & Sumbangan Input Lain $(\mathrm{Rp} / \mathrm{Kg})$ & (9) \\
\hline 10 & Nilai Output $(\mathrm{Rp} / \mathrm{Kg})$ & $(10)=(4) \times(6)$ \\
\hline \multirow[t]{2}{*}{11} & a. Nilai Tambah $(\mathrm{Rp} / \mathrm{Kg})$ & $(11 a)=(10)-(9 a+9 b)(8)$ \\
\hline & b. Rasio Nilai Tambah (\%) & $(11 b)=(11 a) /(10) \times 100$ \\
\hline \multirow[t]{2}{*}{12} & a. Pendapatan Tenaga Kerja (Rp/Kg) & $(12 a)=(5) \times(7)$ \\
\hline & Tingkat Keuntungan(\%) & $(12 b)=(12 a) /(11 a) \times 100$ \\
\hline \multirow[t]{3}{*}{13} & a. Keuntungan $(\mathrm{Rp} / \mathrm{Kg})$ & $(13 a)=(11 a)-(12 a)$ \\
\hline & b. Tingkat Keuntungan (\%) & $(13 b)=(13 a) /(11 a) \times 100$ \\
\hline & Balas Jasa Pemilik Faktor Produksi & \\
\hline \multirow[t]{4}{*}{14} & Marjin $(\mathrm{Rp} / \mathrm{Kg})$ & $(14)=(10)-(8)$ \\
\hline & a. Pendapatan Tenaga Kerja Langsung (\%) & $(14 a)=(12 a) /(14) \times 100$ \\
\hline & b. Sumbangan Input Lain (\%) & $(14 b)=(9 a+9 b) /(14) \times 100$ \\
\hline & c. Keuntungan Perusahaan (\%) & $(14 c)=(13 a) /(14) \times 100$ \\
\hline
\end{tabular}

Sumber: Hayami (1987) dalam Maharani (2013).

\section{Analisis Pemasaran \\ Biaya Pemasaran}

Biaya pemasaran ikan patin dan ikan lele serta produk agroindustri ikan salai patin dan lele tentukan menggunakan rumus menurut Soekartawi (1995) dalam Mulatini (2016), sebagai berikut: $\mathrm{Bp}=\mathrm{B} 1+\mathrm{B} 2+\mathrm{B} 3+\mathrm{B} 4+\mathrm{B} 5+\mathrm{B} 6+\mathrm{B} 7+\mathrm{B} 8+\mathrm{Bn} .$.
Keterangan :

$\mathrm{RCR}=$ Return Cost Of Ratio

$\mathrm{TR}=$ Total penerimaan (Rp/Proses produksi)

$\mathrm{TC}=$ Total biaya $(\mathrm{Rp} /$ Proses produksi)

Kriteria yang digunakan dalam penilaian efisiensi usaha adalah :

RCR > 1, Usaha sudah efisien dan menguntungkan.

$\mathrm{RCR}=1$, Usaha berada pada titik impas (BEP).

$\mathrm{RCR}<1$, Usaha tidak menguntungkan.

\section{Nilai Tambah Ikan Salai Patin dan Lele}

Perhitungan nilai tambah dilakukan menggunakan model menurut Hayami (1987) dalam Maharani (2013). Dasar perhitungan nilai tambah adalah per kg bahan baku. 


$$
\begin{aligned}
& \text { B6 }=\text { Biaya Tenaga Kerja }(\mathrm{Rp} / \mathrm{Kg}) \\
& \text { B7 }=\text { Biaya Label Harga }(\mathrm{Rp} / \mathrm{Kg}) \\
& \text { B8 }=\text { Biaya Sewa Tempat }(\mathrm{Rp} / \mathrm{Kg})
\end{aligned}
$$

\section{Margin Pemasaran}

Marjin pemasaran pada "Usaha Ikan Sedap" ditentukan dengan menggunakan rumus menurut Saefuddin dan Hanafiah (1986) dalam Mulatini (2016), sebagai berikut :

$$
\mathrm{M}=\mathrm{H}_{\mathrm{K}}-\mathrm{H}_{\mathrm{P}}
$$

Dimana:

$$
\begin{aligned}
& \mathrm{M}=\text { Marjin pemasaran }(\mathrm{Rp} / \mathrm{Kg}) \\
& \mathrm{HK}=\text { Harga ditingkat konsumen }(\mathrm{Rp} / \mathrm{Kg}) \\
& \mathrm{HP}=\text { Harga ditingkat produsen }(\mathrm{Rp} / \mathrm{Kg})
\end{aligned}
$$

\section{Keuntungan Pemasaran}

Menghitung keuntungan yang diterima pengusaha digunakan rumus menurut Soekartawi (1995) sebagai berikut :

$$
\pi=\mathrm{M}-\mathrm{B} \text {. }
$$

Dimana:

$$
\begin{aligned}
& \pi=\text { Keuntungan Pemasaran }(\mathrm{Rp} / \mathrm{Kg}) \\
& \mathrm{M}=\text { Marjin Pemasaran }(\mathrm{Rp} / \mathrm{Kg}) \\
& \mathrm{B}=\text { Biaya Pemasaran }(\mathrm{Rp} / \mathrm{Kg})
\end{aligned}
$$

\section{HASIL DAN PEMBAHASAN}

\section{Profil Usaha Ikan Salai Sedap}

Profil usaha merupakan gambaran umum mengenai kondisi usaha yang sedang dijalankan oleh pengusaha. "Usaha ikan salai sedap" berada di Kelurahan Air Dingin Kecamatan Bukit Raya Kota Pekanbaru. Usaha ini sudah berdiri sejak tahun 2010, pengusaha fokus pada budidaya ikan patin dan lele hingga agroindustrinya. Pemilik usaha berusia 43 tahun, dan berpendidikan sarjana (S1), sehingga memungkinkan mengembangkan usahanya secara professional. Modal usaha awal yang digunakan oleh pengusaha yaitu dengan meminjam pada lembaga keuangan yaitu bank BTN sebanyak Rp 35.000.0000.

Kegiatan usaha mulai dari pembudidayaan sampai pengolahan ikan segar (patin dan lele) menjadi ikan salai. Kegiatan usaha dilakukan setiap hari selama satu periode (6 bulan), dengan pemanenan ikan secara selektif, yaitu berat ikan lele 120-140 gram/ekor (berkisar 7-8 ekor $/ \mathrm{kg}$ ) dan untuk ikan patin dengan berat 250-300 gram/ekor (berkisar 3-4 ekor $/ \mathrm{kg}$ ). Usaha ini telah memiliki izin usaha dari Dinas Kesehatan P-IRT No. 2061471010156-19, sertifikasi halal dari
LPPOM 05030003871211 serta bersertifikat cara pengolahan ikan yang baik No. 9182/14/SKP/AS/V/2018.

Berdasarkan kriteria agroindustri menurut Hayami dalam Maharani (2013), maka agroindustri ikan salai patin dan lele di Kelurahan Air Dingin Kecamatan Bukit Raya adalah skala usaha industri rumah tangga (home processing). Pengolahan ikan salai patin dan lele, sudah berlangsung pada bangunan yang terpisah dengan tempat tinggal pengusaha, namun masih satu pekarangan. Berdasarkan dari tingkat pengolahan bahan baku (degree of transformation) menurut Austin dalam Hamidi dan Septina (2006), usaha ini termasuk dalam tingkat pengolahan ketiga, yaitu pengolahan dengan cara memasak.

\section{Subsistem Penyediaan Sarana Produksi Ikan Patin dan Ikan Lele}

Penyediaan sarana produksi merupakan kegiatan subsistem hulu yang membantu kegiatan "Usaha Ikan Salai Sedap" untuk menghasilkan output. Input dan saprotan untuk usaha (kolam, benih, pakan, obat-obatan, tenaga kerja dan bahan penunjang lainnya tersedia.

\section{Subsistem Usahatani Ikan Patin dan Ikan Lele}

Teknologi budidaya ikan patin dan lele yang dilakukan pengusaha mulai dari persiapan kolam hingga panen dan pasca panen pada umumnya berpedoman pada teori-teori yang ada. Lebih jelasnya disajikan pada Tabel 2 . Pada Tabel 2 nampak teknologi budidaya yang dilakukan pengusaha dan teori berbeda pada kegiatan persiapan kolam pengusaha tidak melakukan kegiatan pemupukan, pengapuran kolam, pengisian air dilakukan oleh pengusaha berbeda untuk kolam ikan patin dan lele. Selanjutnya pada kegiatan pemanenan yang dilakukan oleh pengusaha secara selektif sesuai dengan bobot ikan yaitu berat ikan lele 120-140 gram/ekor (berkisar 7-8 ekor/kg) dan untuk ikan patin dengan berat 250-300 gram/ekor (berkisar 3-4 ekor/kg) dan pengusaha langsung mengolah ikan segar (patin dan lele) menjadi ikan salai.

Pendapatan pada usahatani merupakan perolehan dari kegiatan usaha mulai dari kegiatan penebaran benih sampai panen, dapat dilihat pada Tabel 3 . 
Tabel 2. Perbandingan Teknologi Budidaya Ikan Patin dan Lele Secara Teori dengan Praktek pada Usaha Ikan Salai Sedap di Kelurahan Air Dingin Kecamatan Bukit Raya Kota Pekanbaru Tahun 2019.

\begin{tabular}{|c|c|c|c|}
\hline No. & $\begin{array}{l}\text { Teknologi } \\
\text { Budidaya }\end{array}$ & Teori (Mulatini, 2016) & $\begin{array}{l}\text { Praktek pada Usaha Ikan Salai } \\
\text { Sedap }\end{array}$ \\
\hline 1 & Persiapan kolam & $\begin{array}{l}\text { Melakukan pemupukan dan pengapuran } \\
\text { kolam }\end{array}$ & $\begin{array}{l}\text { Kegiatan pemupukan } \\
\text { pengapuran tidak dilakukan }\end{array}$ \\
\hline 2 & $\begin{array}{l}\text { Pengisisn air } \\
\text { kolam }\end{array}$ & $\begin{array}{l}\text { Air kolam ikan patin } 1,2-1,5 \mathrm{~m} \text {, dan ikan lele } \\
1-1,2 \mathrm{~m} \text {, setelah pengisian kolam dibiarkan } \\
\text { selama } 2 \text { hari. }\end{array}$ & $\begin{array}{l}\text { Air kolam ikam patin } 1,5 \mathrm{~m} \text { dan } \\
\text { dan ikan lele } 1 \mathrm{~m} \text {, kemudian } \\
\text { dibiarkan selama } 2 \text { hari. }\end{array}$ \\
\hline 3 & Penebaran bibit & Pagi hari atau sore hari & Pagi atau sore hari \\
\hline 4 & Pemberian Pakan & Dilakukan 4-5 kali & Dilakukan 4-5 kali \\
\hline 5 & $\begin{array}{l}\text { Frekuensi Pem- } \\
\text { berian Pakan }\end{array}$ & $\begin{array}{l}\text { Frekuensi pemberian pakan yaitu } 3-6 \% \text { dari } \\
\text { bobot berat ikan }\end{array}$ & $\begin{array}{l}\text { Sesuai, frekuensi pemberian } \\
\text { pakan yaitu 3-6\% dari bobot berat } \\
\text { ikan }\end{array}$ \\
\hline 6 & $\begin{array}{l}\text { Hama } \\
\text { Penyakit }\end{array}$ & $\begin{array}{l}\text { Hama seperti burung, ular,penyakit seperti } \\
\text { parasit oleh jamur dan bakteri }\end{array}$ & $\begin{array}{l}\text { Sesuai, hama seperti burung, } \\
\text { ular,musang dan penyakit seperti } \\
\text { parasit oleh jamur dan bakteri }\end{array}$ \\
\hline 7 & Pemanenan & $\begin{array}{lcc}\text { Waktu panen berumur } & 2,5-3,5 & \text { bulan. } \\
\text { Pemanenan dilakukan secara selektif } & \end{array}$ & $\begin{array}{l}\text { Tidak sesuai, waktu panen } \\
\text { berumur } 3 \text { bulan. Pemanenan } \\
\text { dilakukan secara selektif }\end{array}$ \\
\hline 8 & Pasca panen & $\begin{array}{l}\text { Pengembalian kondisi seperti semula, } \\
\text { pengankutan hasil panen, dan menjualnya. }\end{array}$ & $\begin{array}{l}\text { Pengembalian kondisi kolan } \\
\text { seperti semuka, pengangkutan } \\
\text { hasil panen, dan mengolah ikan } \\
\text { segar menjadi ikan salai. }\end{array}$ \\
\hline
\end{tabular}

Tabel 3. Rekapitulasi Biaya Produksi, Pendapatan, Keuntungan dan Efisiensi Usahatani Ikan Patin dan Lele di Kelurahan Air Dingin Kecamatan Bukit Raya Kota Pekanbaru Tahun 2019.

\begin{tabular}{|c|c|c|c|c|c|}
\hline No. & Uraian & Jumlah & Harga $(\mathrm{Rp})$ & Nilai (Rp) & Persentase \\
\hline \multirow[t]{3}{*}{1} & Produksi & & & & \\
\hline & a. Ikan Patin $(\mathrm{Kg})$ & 1.900 & 16.500 & $31.350 .000,00$ & \\
\hline & b. Ikan Lele (Kg) & 2.375 & 14.500 & $34.437 .500,00$ & \\
\hline \multirow{23}{*}{$\begin{array}{l}2 \\
3\end{array}$} & Pendapatan Kotor & & & $65.787 .500,00$ & \\
\hline & Biaya & & & & \\
\hline & A. Biaya Variabel & & & & \\
\hline & 1. Bibit & & & & \\
\hline & a. Patin (Ekor) & 10.000 & 250 & $2.500 .000,00$ & 8,48 \\
\hline & b. Lele (Ekor) & 14.000 & 125 & $1.750 .000,00$ & 5,93 \\
\hline & 2. Pakan $(\mathrm{Kg})$ & & & & \\
\hline & a. Ikan Patin & & & & \\
\hline & - F 99 & 60 & 3.625 & $217.500,00$ & \\
\hline & $-F 500$ & 45 & 4.875 & $219.375,00$ & 5.71 \\
\hline & - F 1000 & 45 & 6.625 & $298.125,00$ & \\
\hline & $-781-2$ & 150 & 6.325 & $948.750,00$ & \\
\hline & b. Ikan Lele & & & & \\
\hline & - F 99 & 600 & 3.625 & $2.175 .000,00$ & \\
\hline & $-781-1$ & 900 & 11.750 & $10.575 .000,00$ & 75,41 \\
\hline & $-781-2$ & 1.500 & 6.325 & $9.487 .500,00$ & \\
\hline & 3. Biaya Tenaga Kerja (HOK) & 9,25 & 90.000 & $832.500,00$ & 2,82 \\
\hline & 4. Biaya Listrik (KWh) & 202,90 & 1.380 & $280.000,00$ & 0,95 \\
\hline & Total Biaya Variabel & & & $29.283 .750,00$ & \\
\hline & B. Biaya Tetap & & & & \\
\hline & Biaya Penyusutan Alat & & & $206.466,67$ & 0,70 \\
\hline & Total Biaya Tetap & & & $206.466,67$ & \\
\hline & Total Biaya Produksi & & & $29.490 .216,67$ & 100,00 \\
\hline 4 & Pendapatan Bersih & & & $36.297 .283,33$ & \\
\hline 5 & Efisiensi Usahatani & & & 2,23 & \\
\hline
\end{tabular}


Pada Tabel 3, Pengalokasian biaya yang terbesar digunakan untuk pembelian pakan ikan lele sebesar Rp 22.237.500,- (75,41\%). Hal ini dikarenakan ikan lele membutuhkan makanan yang lebih banyak untuk mendukung pertumbuhannya, kemudian disusul dengan pembelian bibit ikan patin sebesar $\mathrm{Rp}$ $2.500 .000,-(8,48 \%)$. Jumlah bibit yang ditebarkan per proses produksi untuk ikan patin sebanyak 10.000 ekor dan ikan lele 14.000 ekor, dengan jumlah produksi yang diperoleh untuk ikan patin sebanyak $1.900 \mathrm{~kg}$ dan ikan lele 2.375 $\mathrm{kg}$. Berat panen rata-rata ikan patin adalah 250 gr/ekor (1 kg terdapat 4 ekor ikan patin), dan berat rata-rata ikan lele adalah 150 gr/ekor $(1 \mathrm{~kg}$ terdapat 7 ekor). Pendapatan bersih usahatani (budidaya perikanan patin dan lele) pada "Usaha Ikan Salai Sedap" diperoleh sebanyak Rp 36.297.383,33,-,dengan nilai RCR 2,23. Hal ini berarti usaha ini efisien atau layak untuk dikembangkan, karena setiap $\operatorname{Rp} 1,00$ biaya yang dikeluarkan dalam kegiatan usaha akan memberikan keuntungan sebesar Rp 2,23,-.

\section{Subsistem Agroindustri}

Agroindustri ikan patin dan lele merupakan serangkaian kegiatan pengolahan ikan patin dan lele yang meliputi pembersihan ikan segar, penyusunan di oven, pengemasan, penyusunan di box penyimpanan, sehingga produk ikan salai patin dan lele memiliki nilai tambah. Kegiatan subsistem agroindustri ikan salai patin dan lele terdiri dari beberapa kegiatan pengelolaan, yaitu penyediaan sarana input, teknologi produksi, yang membutuhkan biaya produksi. Kegiatan agroindustry akan memberikan nilai tambah dan pendapatan bagi pengusaha. Setiap kali proses produksi ikan salai menggunakan ikan lele dan patin segar masingmasing sebanyak $150 \mathrm{Kg}$. Harga bahan baku yang digunakan ikan lele segar $\mathrm{Rp} 16.500,00 / \mathrm{Kg}$ dan ikan patin segar $\mathrm{Rp} 6.000,00 / \mathrm{Kg}$. Tabel 6 menampilkan penggunaan bahan baku dan penunjang agroindustry "Usaha Ikan Salai Sedap" per proses produksi.

Tabel 4. Distribusi Biaya, Produksi, pendapatan Per Proses Produksi (tiga hari) Pada Usaha Ikan Salai Sedap di Kelurahan Air Dingin Kecamatan Bukit Raya Kota Pekanbaru Tahun 2019

\begin{tabular}{|c|c|c|c|c|c|}
\hline No. & Uraian & Jumlah & Harga (Rp) & Nilai (Rp) & $\begin{array}{l}\text { Nilai (Rp/Proses } \\
\text { Produksi) }\end{array}$ \\
\hline A & Biaya Variabel & & & & \\
\hline \multirow[t]{3}{*}{1} & Bahan Baku (Kg) & & & & \\
\hline & a. Ikan Patin & 150 & $14.500,00$ & $2.175 .000,00$ & $2.175 .000,00$ \\
\hline & b. Ikan Lele & 150 & $16.500,00$ & $2.475 .000,00$ & $2.475 .000,00$ \\
\hline \multirow[t]{6}{*}{2} & Bahan Pendukung (Unit) & & & & \\
\hline & 1. Kayu Bakar & 2 & $200.000,00$ & $400.000,00$ & $40.000,00$ \\
\hline & 2. Sarung Tangan & 16 & $7.000,00$ & $112.000,00$ & $11.200,00$ \\
\hline & $\begin{array}{l}\text { 3. Plastik Packing } \\
\text { (Lembar) }\end{array}$ & & & & \\
\hline & $-200 \mathrm{gr}$ & 188 & 435,29 & $81.834,52$ & $81.834,52$ \\
\hline & $-250 \mathrm{gr}$ & 150 & 435,29 & $65.293,50$ & $65.293,50$ \\
\hline \multirow[t]{2}{*}{3} & Total Biaya Bahan & & & & \\
\hline & Pendukung & & & $659.128,02$ & $198.328,02$ \\
\hline 4 & Biaya Tenaga Kerja & 2 & $90.000,00$ & $180.000,00$ & $180.000,00$ \\
\hline 5 & Listrik & & & $17.500,00$ & $17.500,00$ \\
\hline 6 & Total Biaya Variabel & & & $856.628,02$ & $395.828,02$ \\
\hline \multirow[t]{2}{*}{ B } & Biaya Tetap & & & & $39.888,11$ \\
\hline & Total Biaya Produksi & & & & 5.679.827.17 \\
\hline \multirow[t]{3}{*}{$\mathrm{C}$} & Produksi & & & & \\
\hline & -Ikan Salai Patin (kg) & 37,5 & $92.000,00$ & & $3.450 .000,00$ \\
\hline & -Ikan Salai Lele (kg) & 37,5 & $115.000,00$ & & $4.312 .500,00$ \\
\hline \multirow[t]{3}{*}{$\mathrm{D}$} & Pendapatan & & & & \\
\hline & -Pendapatan Kotor & & & & $7.762 .500,00$ \\
\hline & -Pendekatan Bersih & & & & 2.714.572.61 \\
\hline E & Efisiensi (RCR) & & & & 1,54 \\
\hline
\end{tabular}

Pada Tabel 4. dapat dilihat satu kali penyalaian dibutuhkan masing-masing 150 ekor ikan segar. Pendapatan bersih dari pengolahan ikan segar menjadi ikan salai sebesar 2.714.572,61/proses produksi. Dalam satu bulan terdapat 10 kali proses produksi, penggunaan 
bahan baku usaha ikan salai sedap selama sebulan masing-masing yaitu $1500 \mathrm{Kg}$ untuk ikan patin dan $1500 \mathrm{Kg}$ ikan lele, apabila bahan baku kurang maka pengusaha mendatangkan bahan baku dari luar seperti dari sekolah SMK Pertanian jurusan perikanan.

Sehingga pendapatan bersih yang diterima oleh pengusaha selama sebulan sebesar
Rp 27.145.726,10. Nilai RCR diperoleh 1,54, hal ini menunjukkan bahwa usaha efisien.

\section{Nilai Tambah}

Nilai tambah adalah pertambahan nilai suatu komoditas karena komoditas tersebut telah mengalami pengolahan. Nilai tambah yang diperoleh dari pengolahan ikan patin dan ikan lele menjadi ikan ditampilkan pada Tabel 5.

Tabel 5. Nilai Tambah Metode Hayami pada Agroindustri Ikan Salai Patin dan Lele pada Usaha Ikan Salai Sedap di Kelurahan Air Dingin Kecamatan Bukit Raya Tahun 2019

\begin{tabular}{|c|c|c|c|}
\hline \multirow[t]{2}{*}{ No } & \multirow[t]{2}{*}{ Variabel } & \multicolumn{2}{|c|}{ Nilai } \\
\hline & & Ikan Patin & Ikan Lele \\
\hline \multicolumn{4}{|c|}{ Output, Input, dan Harga } \\
\hline 1 & Output (Kg) & 37,5 & 37,5 \\
\hline 2 & Bahan Baku (Kg) & 150 & 150 \\
\hline 3 & Tenaga Kerja Langsung (HOK) & 2,61 & 2,61 \\
\hline 4 & Faktor Konversi & 0,25 & 0,25 \\
\hline 5 & Koefisien Tenaga Kerja $(\mathrm{HOK} / \mathrm{Kg})$ & 0,02 & 0,02 \\
\hline 6 & Harga Output $(\mathrm{Rp} / \mathrm{Kg})$ & $92.000,00$ & $115.000,00$ \\
\hline 7 & Upah Tenaga Kerja (Rp/HOK) & $90.000,00$ & $90.000,00$ \\
\hline \multicolumn{4}{|c|}{ Penerimaan dan Keuntungan } \\
\hline 8 & Harga Bahan Baku (Rp/Kg) & $14.500,00$ & $16.500,00$ \\
\hline $9 \mathrm{a}$ & Sumbangan Input Lain (Produksi) (Rp/Kg) & & \\
\hline $9 \mathrm{~b}$ & Sumbangan Input Lain (Operasional) $(\mathrm{Rp} / \mathrm{Kg})$ & 872,97 & 872,97 \\
\hline 10 & Nilai Output $(\mathrm{Rp} / \mathrm{Kg})$ & $23.307,00$ & $29.133,00$ \\
\hline \multirow[t]{2}{*}{11} & a. Nilai Tambah $(\mathrm{Rp} / \mathrm{Kg})$ & $7.933,70$ & $11.760,00$ \\
\hline & b. Rasio Nilai Tambah (\%) & 34,04 & 40,37 \\
\hline \multirow[t]{2}{*}{12} & a. Pendapatan Tenaga Kerja (Rp/Kg) & $1.566,00$ & $1.566,00$ \\
\hline & Pangsa Tenaga Kerja (\%) & 19,74 & 13,32 \\
\hline \multirow[t]{2}{*}{13} & a. Keuntungan $(\mathrm{Rp} / \mathrm{Kg})$ & $6.368,00$ & $10.194,00$ \\
\hline & b. Tingkat Keuntungan (\%) & 80,26 & 86,68 \\
\hline \multicolumn{4}{|c|}{ Batas Jasa Pemilik Faktor Produksi } \\
\hline \multirow[t]{4}{*}{14} & Marjin $(\mathrm{Rp} / \mathrm{Kg})$ & $8.807,00$ & $12.633,00$ \\
\hline & a. Pendapatan Tenaga Kerja Langsung (\%) & 17,78 & 12,40 \\
\hline & b. Sumbangan Input Lain (\%) & $21.836,60$ & $15.222,25$ \\
\hline & c. Keuntungan Pengusaha (\%) & 72,31 & 80,69 \\
\hline \multirow[t]{2}{*}{15} & Efisiensi & & \\
\hline & $\mathrm{RCR}$ & 1,32 & 1,48 \\
\hline
\end{tabular}

Pada Tabel 5 nampak nilai tambah yang diperoleh dari pengolahan ikan lele menjadi ikan salai lele Rp 11.760/kg, lebih tinggi dibandingkan ikan patin Rp 7.933,70. Hal ini menunjukkan pengolahan ikan salai lele lebih menguntungkan ( $\operatorname{Rp~Rp~6.368,00/kg~)~daripada~}$ ikan salai patin ( $\mathrm{Rp} 10.194,00 / \mathrm{kg}$ ). Tingginya keuntungan pada pengolahan ikan salai lele diantaranya disebabkan harga jual dari lele lebih tinggi.

\section{Subsistem Pemasaran}

Pemasaran ikan salai pada Usaha Ikan Salai Sedap dilakukan dengan satu saluran, yaitu pengusaha menyalurkan produk (ikan salai) ke pedagang pengecer (swalayan yaitu : Hypermart, Mega Rasa, Pasar Buah,Silungkang dan pusat oleh-oleh Pekanbaru) dan selanjutnya pengecer menyalurkan ke konsumen akhir. Biaya, marjin dan farmer share dalam pemasaran dapat dilihat pada Tabel 6 . 
Tabel 6. Biaya Pemasaran, Marjin Pemasaran, Keuntungan Pemasaran, Farmer Share dan Efisiensi Pemasaran pada Usaha Ikan Salai Sedap di Kelurahan Air Dingin Kecamatan Bukit Raya Tahun 2019.

\begin{tabular}{|c|c|c|c|}
\hline \multirow[t]{2}{*}{ No. } & \multirow[t]{2}{*}{ Uraian } & \multicolumn{2}{|c|}{ Nilai } \\
\hline & & $(\mathrm{Rp} / \mathrm{kg})$ & \\
\hline & Pengusaha & & \\
\hline & Karton $(\mathrm{kg})$ & 26,67 & $2.000,00$ \\
\hline \multirow[t]{15}{*}{1} & Solasiban (lembar) & 100,00 & $7.500,00$ \\
\hline & Kertas Merk Jual 200 gr (lembar) & $3.008,00$ & $112.800,00$ \\
\hline & Kertas Merk Jual $250 \mathrm{gr}$ (lembar) & $2.400,00$ & $90.000,00$ \\
\hline & Label Harga Jual (Rp/botol) & 399,00 & $59.850,00$ \\
\hline & Tinta Stempel Kadaluarsa (unit) & 87,72 & $30.000,00$ \\
\hline & Transportasi (HOK) & 405,33 & $30.400,00$ \\
\hline & Tenaga Kerja & 133,33 & $10.000,00$ \\
\hline & Total Biaya & $6.560,05$ & $342.550,00$ \\
\hline & Keuntungan & $98.932,67$ & $7.419 .950,00$ \\
\hline & Harga Jual & $103.500,00$ & $7.762 .500,00$ \\
\hline & a. Ikan Salai Patin & $92.000,00$ & $3.450 .000,00$ \\
\hline & b. Ikan Salai Lele & $115.000,00$ & $4.312 .500,00$ \\
\hline & Farmer Share (\%) & & \\
\hline & a. Ikan Salai Patin & & 76,07 \\
\hline & b. Ikan Salai Lele & & 79,31 \\
\hline \multirow[t]{7}{*}{2} & Pusat Oleh-oleh Pekanbaru & & \\
\hline & Harga Beli & $207.000,00$ & $7.762 .500,00$ \\
\hline & a. Ikan Salai Patin & $92.000,00$ & $3.450 .000,00$ \\
\hline & b. Ikan Salai Lele & $115.000,00$ & $4.312 .500,00$ \\
\hline & Harga Jual & $265.940,00$ & \\
\hline & a. Ikan Salai Patin & $120.940,00$ & \\
\hline & b. Salai Lele & $145.000,00$ & $9.972 .750,00$ \\
\hline \multirow[t]{3}{*}{3} & Marjin Pemasaran & $58.900,00$ & \\
\hline & a. Ikan salai patin & $28.940,00$ & $2.210 .250,00$ \\
\hline & b. Ikan salai lele & $30.000,00$ & \\
\hline \multirow[t]{3}{*}{4} & Efisiensi & & \\
\hline & a. Ikan Salai Patin (\%) & & 19,70 \\
\hline & b. Ikan Salai Lele $(\%)$ & & 25,18 \\
\hline
\end{tabular}

Pada Tabel 6, total biaya dalam pemasaran ikan salai patin dan lele sebesar Rp 6.560,05/Kg atau $\mathrm{Rp} \mathrm{342.550,-/proses} \mathrm{produksi.}$ Biaya Pemasaran tersebut terdiri dari pembelian peralatan untuk keperluan memasarkan, biaya transportasi, dan tenaga kerja. Harga jual oleh pengusaha ikan salai sedap, untuk harga ikan salai patin $\mathrm{Rp} 92.000,00 / \mathrm{Kg}$ dan ikan salai lele dengan harga $\mathrm{Rp} 115.000,00 / \mathrm{Kg}$. Total harga kedua ikan salai yaitu Rp 207.000,00. Sedangkan harga yang diterima oleh konsumen, untuk ikan salai patin $\mathrm{Rp} 120.940,00 / \mathrm{Kg}$ dan ikan salai lele sebesar Rp 145.000,00/Kg. Total harga kedua ikan salai yaitu Rp 265.940,00. Sehingga di peroleh marjin pemasaran (selisih antara harga antara pengusaha dan pedagang pengecer) sebesar $\mathrm{Rp} 28.940,00 / \mathrm{Kg}$ ikan salai patin dan Rp 30.000,00/Kg ikan salai lele. Nilai farmer share pemasaran ikan salai patin pada tingkat pengusaha yaitu sebesar 76,07\%, sedangkam pada ikan salai lele sebesar dan lele pada tingkat pengusaha sebesar $79,31 \%$.

\section{Subsistem Penunjang Agribisnis}

Subsistem penunjang merupakan subsistem yang memberikan dukungan terhadap kegiatan agribisnis. Lembaga keuangan, penyuluh dan KPPI (Kelompok Peternak dan Pengolah Ikan), transportasi yang mendukung kegiatan pemasaran merupakan lembaga yang penting dalam subsistem penunjang. Lembaga keuangan pada usaha Ikan Salai Sedap berperan dalam mendukung permodalan yang dikelola oleh pengusaha. Hubungan antara pelaku agribisnis dengan penyuluhan belum ada, pengusaha mengusahakan usahanya sendiri dengan cara memberikan agunan atau jaminan kepada pihak lembaga keuangan atau bank.

Transportasi juga salah satu penunjang pada usaha Ikan Salai Sedap, transportasi yang 
digunakan oleh pengusaha yaitu berupa sepeda motor yang mendukung kegiatan pemasaran pada "Usaha Ikan Salai Sedap" yaitu ikan salai patin dan lele. Transportasi sebagai penunjang mempermudah konsumen untuk mendapatkan ikan salai sedap di pusat oleh-oleh Pekanbaru.

\section{Keuntungan Usaha Agribisnis pada Usaha Ikan Salai Sedap}

Pelaksanaan kegiatan Usaha Ikan Salai Sedap yang dimiliki oleh pengusaha, yang menerapkan sistem agribisnis mendapatkan keuntungan yang berbeda-beda untuk setiap subsistem yang sudah dijalankan. Semua keuntungan yang diperoleh oleh pengusaha selama satu kali proses produksi adalah keuntungan dalam usaha agribisnis ikan salai lele dan patin. Keuntungan yang dihasilkan dari Usaha Ikan Salai Sedap yaitu ikan salai lele dan ikan salai patin merupakan hasil dari keuntungan usahatani, keuntungan ushaa agroindustri dan keuntungan pemasaran ikan salai lele dan salai patin (Tabel 7).

Tabel 7. Keuntungan Usaha Agribisnis Pada "Usaha Ikan Salai Sedap" di Kelurahan Air Dingin Kecamatan Bukit Raya Tahun 2019

\begin{tabular}{|c|c|c|c|c|}
\hline No. & Subsistem Agribisnis & $\begin{array}{c}\text { JumlahPenggunaan } \\
\text { Bahan Baku } \\
\text { (Ekor/Kg/proses) }\end{array}$ & $\begin{array}{l}\text { Jumlah Produksi } \\
\text { (Kg/Proses) }\end{array}$ & $\begin{array}{c}\text { Keuntungan } \\
\text { (Rp/proses produksi) }\end{array}$ \\
\hline & Usahatani : & 24.000 & 4.275 & $36.297 .283,32$ \\
\hline \multirow[t]{3}{*}{1} & a. Ikan Patin & 10.000 & 2.375 & $26.506 .766,66$ \\
\hline & b. Ikan Lele & 14.000 & 1.900 & $9.790 .516,66$ \\
\hline & Agroindustri: & 300 & 75 & 2.233.543,96 \\
\hline \multirow[t]{3}{*}{2} & a. Ikan Salai Patin & 150 & 37,5 & $843.792,49$ \\
\hline & b. Ikan Salai Lele & 150 & 37,5 & $1.389 .751,47$ \\
\hline & Pemasaran : & 300 & 75 & $7.419 .950,00$ \\
\hline \multirow[t]{3}{*}{3} & a. Ikan Salai Patin & 150 & 37,5 & $3.278 .725,00$ \\
\hline & b. Ikan Salai Lele & 150 & 37,5 & $4.141 .225,00$ \\
\hline & & Jumlah & & $45.950 .777,28$ \\
\hline
\end{tabular}

Hasil produksi dari kegiatan usahatani ikan patin dan lele berjumlah $4.275 \mathrm{Kg} /$ proses produksi. Untuk menghasilkan output atau produk agroindustri ikan salai sedap yaitu ikan salai patin dan lele untuk setiap kali proses produksinya membutuhkan $150 \mathrm{Kg}$ ikan lele dan $150 \mathrm{Kg}$ patin. Untuk memanfaatkan hasil produksi kegiatan budidaya maka kegiatan proses pada agroindustri dan pemasaran ikan salai patin dikalikan dengan 15,83 (hampir 16 kali proses produksi). Sedangkan hasil produksi ikan lele yang dihasilkan dari kegiatan budidaya maka proses agroindustri dan pemasaran ikan lele dapat dilakukan sebanyak 12,66 kali (13 kali proses produksi. Pada Tabel 7 dapat dilihat bahwa, keuntungan yang diperoleh oleh pengusaha dari usaha agribisnis ikan patin dan lele sebesar $\mathrm{Rp} 45.950 .777,28 /$ proses produksi. Keuntungan terbesar yang diperoleh oleh pengusaha berasal dari kegiatan usahatani ikan patin dan lele yaitu sebesar $\mathrm{Rp}$ 36.297.283,32/proses produksi, kemudian diikuti keuntungan dari pemasaran ikan salai lele daan patin sebesar $\mathrm{Rp}$ 7.419.950,- dan keuntungan kegiatan agroindustri ikan salai patin dan lele yaitu sebesar Rp 2.233.543,96/porses produksi.

\section{KESIMPULAN}

Sistem agribisnis yang diterapkan pada“Usaha Ikan Selai Sedap" telah berhasil membuat usaha tersebut berkelanjutan. Secara keseluruhan sarana produksi tersedia dan terpenuhi dengan baik. Ikan patin dan lele segar dari hasil usahatani langsung diolah oleh pengusaha menjadi ikan salai patin dan lele, selanjutnya ikan salai yang dihasilkan dipasarkan melalui lembaga pemasaran.

Kegiatan usaha dilakukan setiap hari,dengan pemanenan yang dilakukan oleh pengusaha secara selektif sesuai dengan bobot ikan yaitu berat ikan lele 120-140 gram/ekor (berkisar 7-8 ekor/kg) dan untuk ikan patin dengan berat 250-300 gram/ekor (berkisar 3-4 ekor/kg). Pengolahan ini memberikan nilai tambah 
yaitu untuk ikan salai patin senilai Rp $7.933,70 / \mathrm{Kg}$ bahan baku dan nilai tambah ikan salai lele senilai Rp 11.760,-.

Keuntungan yang diperoleh oleh pengusaha dari usaha agribisnis ikan patin dan lele sebesar Rp 45.950.777,28/proses produksi. Keuntungan terbesar yang diperoleh oleh pengusaha berasal dari kegiatan usahatani ikan patin dan lele yaitu sebesar $\mathrm{Rp}$ 36.297.283,32/proses produksi, kemudian diikuti keuntungan dari pemasaran ikan salai lele dan patin sebesar Rp 7.419.950,- dan keuntungan kegiatan agroindustri ikan salai patin dan lele yaitu sebesar Rp 2.233.543,96/porses produksi.

Subsistem penunjang yang domonan, terkait dalam mendukung kegiatan usaha agribisnisnis Usaha Ikan Salai Sedap yaitu lembaga keuangan/Bank, penyuluhan \& pelatihan.

\section{DAFTAR PUSTAKA}

Afrianto, Eddy dan Evi Liviawaty. 2002. Pakan Ikan. Kanisius. Yogyakarta.

Arikunto, S. 2010. Prosedur Penelitian Suatu Pendekatan Praktik. Rineka Cipta: Jakarta.

Badan Pusat Statistik. 2018. Kota Pekanbaru dalam Angka. Pekanbaru.

Bakar, S.N.A., Hassan MD, Jintasataporn O, Hasliza AH, Murni Marlina AK, Nurhidayahanum $\mathrm{H}$ and Fairus MSS. 2018. Evaluation of striped catfish, Pangasius hypophthalmus (Sauvage, 1878) dried viscera and its intestinal putative probiont on juvenile African catfish, Clarias gariepinus (Burchell, 1822) growth performance. International Journal of Fisheries and Aquatic Studies, 7(1): 249-254.

Bokings L. U, Yuniarti K, Juliana. 2017. Pertumbuhan dan Kelangsungan Hidup Benih Ikan Patin Siam (Pangasius Hypophalmus) yang Diberi Pakan Buatan, Cacing Sutra (Tubifex Sp.) dan Kombinasi Keduanya. Junral Ilmiah Perikanan dan Kelautan. Fakultas Perikanan dan Ilmu Kelautan Universitas Gorontalo, 5(3):8289.

Djarijah AS. 2001. Budidaya Ikan Patin.

Kanisius. Yogyakarta.
Firdaus. M. 2012. Manajemen Agribisnis. PT. Bumi Aksara : Jakarta.

Hamidi, W. 2016. Analisis Nilai Tambah Agroindustri Abon Ikan Patin di Desa Koto Mesjid Kecamatan XIII Koto Kampar Kabupaten Kampar Provinsi Riau (Studi Kasus Pada Cv. Graha Pratama Fish). Jurnal Agribisnis. 18(1):54-64.

Maharani CND, Lestari DAH, Kasymir E. 2013. Analaisis Nilai Tambah dan Kelayakan Usaha Pengolahan Limbah Padat Ubi Kayu (Onggok) Di Kecamatan Pekalongan Kabupaten Lampung Timur. Jurnal Ilmu-Ilmu Agribisnis, 1(4) 284290.

Maulidah, S. 2012. Sistem Agribisnis. Brawijaya University. Malang.

Muhammad, W.N. dan S. Adriyanto. 2013. Manajemen Budidaya Ikan Lele Dumbo (Clarias gariepinus) di Kampung Lele, Kabupaten Boyolali, Jawa Tengah. Vol.8(1):63-71

Mulatini, T.A. 2016. Studi Agribisnis Usaha Ikan Lele (Kasus pada Koperasi Panco Masua Bakat Group) di Kelurahan Simpang Tiga Kecamatan Bukit Raya Kota Pekanbaru. Skripsi. Fakultas Pertanian. Universitas Islam Riau.

Puspita, R. M dan W.Ahmad. 2014. Budidaya Ikan Patin Cepat Panen. PT. Infra Pustaka, Jakarta.

Saragih, B. 2001. Paradigma Baru Pembangunan Ekonomi Berbasis Pertanian. Yayasan USESE. Bogor. 2004. Membangun Pertanian dalam Perspektif Agrobisnis dalam Ruang. Raja Grafindo Persada. Jakarta.

Sebayang. 2002. Teknologi Pengasapan Ikan bagi Masyarakat Nelayan. Jurnal Pengabdian kepada Masyarakat. Vol.8(28):42-45.

Silalahi, U. 2012. Metode Penelitian Sosial. PT. Refika Aditama: Bandung

Soekartawi. 2001. Pengantar Agroindustri. PT. Raja Grafindo Persada, Jakarta

2003. Agribisnis Teori dan Aplikasinya. PT. Raja Grafindo Persada, Jakarta

2006. Analisis Usaha Tani. UI Press, Jakarta

Umar, Z.A. 2011. Pengembangan Agribisnis Terpadu di Sektor Perikanan. Jurnal Inovasi Volume 8, No.4, Desember 2011. Gorontalo. 
